\title{
The Correlation between Lipoprotein-Associated Phospholipase A2 and Atherosclerosis (ox-LDL) in Centrally Obese Men
}

\author{
Priscilla Dian Ari $^{1,2 *}$, Ellis Susanti ${ }^{2,4}$, Ilham Jaya Patellongi ${ }^{3}$, \\ 'Prodia Clinical Laboratory, Jl. A. Yani, Kompleks Cenderawasih Trade Center, Blok A-6, Samarinda, Indonesia \\ ${ }^{2}$ Post Graduate Program in Clinical Biochemistry, Hasanuddin University, Jl. Perintis Kemerdekaan Km.10. Makassar, Indonesia \\ ${ }^{3}$ Faculty of Medicine, Hasanuddin University, Jl. Perintis Kemerdekaan Km.10. Makassar, Indonesia \\ ${ }^{4}$ Prodia Clinical Laboratory, Jl. Kramat Raya 150, Jakarta, Indonesia \\ ${ }^{*}$ Correspondence: priscilla.dian@prodia.co.id
}

\section{Abstract}

B ACKGROUND: Obesity is closely associated with atherosclerosis. Obesity and atherosclerosis are closely associated with inflammatory disease. Atherosclerosis constitutes a multifactorial disorder affecting the arterial wall, which is initiated by dyslipidemia and exacerbated by inflammation. Plasma levels of lipoprotein-associated phospholipase $\mathrm{A}_{2}$ (Lp$\mathrm{PLA}_{2}$ ) and oxidized low density lipoprotein (ox-LDL) have been identified as risk factors for cardiovascular disease. $\mathrm{Lp}_{\mathrm{PLA}}$ is the sole enzyme responsible for the hydrolysis of oxidized phospholipids (oxPL) on LDL particles in atherosclerosis plaque. Plasma level of oxLDL is associated with inflammation and plays an important role in the development of atherosclerosis. The aim of this study was to assess the correlation between $\mathrm{Lp}-\mathrm{PLA}_{2}$ and atherosclerosis (oxLDL) in centrally obese men.

METHODS: This was a cross-sectional study involving 71 men with central obesity with waist circumference $>90 \mathrm{~cm}$, aged 30-60 years old. Lp-PLA ${ }_{2}$ measurement was done by sandwich enzyme immunoassay. oxLDL measurement was done by ELISA method.

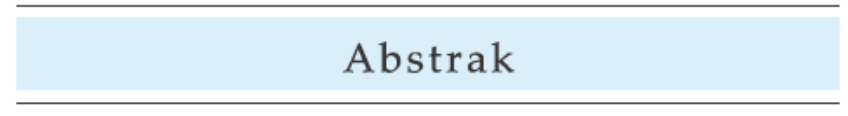

工

ATAR BELAKANG: Obesitas terkait erat dengan aterosklerosis. Obesitas dan aterosklerosis terkait erat dengan inflamasi. Aterosklerosis merupakan gangguan multifaktorial yang mempengaruhi dinding arterial, yang diinisiasi oleh dislipidemia dan diperkuat oleh adanya inflamasi. Lipoprotein-associated phospholipase $\mathrm{A}_{2}$ (Lp-PLA $\mathrm{L}_{2}$ ) dan oxidized low density lipoprotein (ox-LDL) telah diidentifikasi merupakan faktor risiko kardiovaskular. Lp-PLA $A_{2}$ merupakan enzim yang terlibat dalam hidrolisis oxidized phospholipids (oxPL) pada partikel LDL dalam plak aterosklerosis. Konsentrasi oxLDL terkait dengan inflamasi dan berperan penting dalam perkembangan aterosklerosis. Studi ini bertujuan untuk menilai korelasi antara Lp-PLA $_{2}$ dan aterosklerosis (oxLDL) pada pria obesitas sentral.

METODA: Studi ini menggunakan metoda crosssectional yang melibatkan 71 pria dengan obesitas sentral yang ditandai dengan lingkar perut/waist circumference (WC) $>90 \mathrm{~cm}$, berusia 30-60 tahun. Konsentrasi LpPLA2 ditentukan menggunakan metoda sandwich enzyme immunoassay. Penentuan konsentrasi oxLDL dilakukan menggunakan metoda ELISA. 
RESULTS: Results of this study showed that central obesity correlated positively with oxLDL $\left(\mathrm{r}=0.258^{*} ; \mathrm{p}\right.$ $=0.040)$ and Lp-PLA $>422 \mathrm{ng} / \mathrm{mL}$ correlated positively with oxLDL $(r=0.331 * ; \mathrm{p}=0.042)$.

CONCLUSIONS: We conclude that there is a correlation of Lp-PLA ${ }_{2}$ with atherosclerosis (oxLDL) in men with central obesity.

KEYWORDS: obesity, Lp-PLA, oxLDL, atherosclerosis Indones Biomed J 2012; 4 (2): 101-106
RESULTS: Hasil studi menunjukkan bahwa obesitas sentral berhubungan positif dengan oxLDL $\left(r=0,258^{*}\right.$; $\mathrm{p}=0,040)$ dan Lp-PLA $2>422 \mathrm{ng} / \mathrm{mL}$ berkorelasi positif dengan oxLDL $(r=0,331 * ; p=0,042)$.

KESIMPULAN: Hasil studi ini menyimpulkan bahwa terdapat korelasi antara Lp-PLA 2 dengan aterosklerosis (oxLDL) pada pria dengan obesitas sentral.

KATA KUNCI: obesitas, Lp-PLA ${ }_{2}$, oxLDL, aterosklerosis Indones Biomed J 2012; 4 (2): 101-106

\section{Introduction}

One of the most important recent developments in the study on obesity is the emergence of the concept that obesity is characterized by chronic mild inflammation paralleling the situation with other diseases. The basis for this view is that the circulating level of several cytokines and acute phase proteins associated with inflammation is increased in obese individuals (1). Previous studies have demonstrated that enlargement of adipocytes is associated with substantial changes in metabolic functions, e.g. in lipid metabolism (2). It has been hypothesized that such alteration may contribute to the health-related risks of obesity. Obesity is linked to a variety of metabolic disorders such as insulin resistance and atherosclerosis. Abnormal regulation of fat production- derived secretory factors, adipocytokines, is partly responsible for obesity linked metabolic disorders (3).

Lipoprotein-associated phospholipase $\mathrm{A}_{2}\left(\mathrm{Lp}-\mathrm{PLA}^{2}\right)$, also known as platelet-activating factor acetylhydrolase (PAF-AH), is a phospholipase $\mathrm{A}_{2}$ enzyme. In the blood it travels mainly with small-dense low density lipoprotein (sdLDL). It is an enzyme produced by inflammatory cells and hydrolyzes oxidized phospholipids in LDL. LpPLA $^{2}$ is involved in the development of atherosclerosis. Hydrolysis of phospholipids that is associated with lipoprotein particles by the phospholipase $\mathrm{A}_{2}$ family of enzymes leads to modulation of lipoprotein particle phospholipid content and size as well as production of both pro- and antiinflammatory intermediates, all of which may serve as a basis for involvement of these enzymes in the development of atherosclerosis. In human atherosclerotic lesions, two main sources of Lp-PLA ${ }_{2}$ can be identified, including that which is brought into the intima bound to LDL (from the circulation), and that which is synthesized de novo by plaque inflammatory cells (macrophages, $\mathrm{T}$ cells, mast cells). It is used as a marker for cardiac disease. A meta-analysis involving a total of 79.036 participants in 32 prospective studies showed that Lp$\mathrm{PLA}_{2}$ levels are positively correlated with increased risk of developing coronary heart disease and stroke (4). Lipidlowering agents, particularly statins, lower Lp-PLA mass and activity; therefore, $\mathrm{Lp}-\mathrm{PLA}_{2}$ may represent an important target of lipid-lowering therapy for reducing the inflammatory nature of atherosclerosis and plaque vulnerability (16). Lp-PLA ${ }_{2}$ results are categorized into three progressive levels of cardiovascular risk: low $<310$ $\mathrm{ng} / \mathrm{mL}$; moderate $310-422 \mathrm{ng} / \mathrm{mL}$; high $>422 \mathrm{ng} / \mathrm{mL}$ (17).

The mechanisms underlying the pathogenesis of atherosclerosis are complex and affected by interaction among several biological pathways, including those of inflammation, metabolic disorder, and oxidative stress (5). The process of inflammation has been shown pathohistologically in advanced atherosclerotic plaques. Inflammation is mediated by the increasing quantities of proinflammatory cytokines. An early event in the progression of the disease is accumulation of LDL that may become oxidized. LDL can be oxidized enzymatically. With further oxidization, recognition by scavenger receptors occurs, leading to foam cell formation (6).

Oxidative modification of LDL is regarded as a key step in the formation of atherosclerosis. OxLDL involved in atherosclerogenic steps such as endothelial dysfunction, migration of macrophage and smooth muscle 
cells, and release of inflammatory cytokines, induces oxidative stress and incorporated with macrophage transformation into foam cells and atherosclerotic plaque formation (7). Growing evidence indicates a relationship between circulating oxLDL and pathogenic processes of cardiovascular disease. Thus, circulating oxLDL has been established as a biomarker of atherosclerosis (8). The presence of circulating antibodies against oxLDL suggests its availability as an antigen outside the vascular system. Cholesterol crystals, detected not only in necrotic cores but also in the subendothelial areas in early atherosclerotic settings, trigger inflammasome activation, leading to interleukin- $1 \beta$ secretion. Their possible source may be the circulation (6).

\section{Methods}

\section{SUBJECTS}

This study was observational with a cross-sectional design done on a group of centrally obese men $(n=71)$. The subjects' ages were between 30-60 years; they had central obesity with waist circumference $\geq 90 \mathrm{~cm}$. Before commencement of the study, all subjects signed an informed consent. None of the subjects had acute inflammation (hsCRP $\geq 10 \mathrm{mg} / \mathrm{L}$ ), kidney disorder, and nor consuming anti-inflammatory drug. All subjects underwent standardized interviews and physical and laboratory examinations.

\section{ASSAY OF BIOCHEMICAL MARKERS}

The plasma levels of Lp-PLA ${ }_{2}$ were measured using two highly specific monoclonal antibodies for direct measurement of concentration. The PLAC ${ }^{\mathrm{TM}}$ Test Regent Kit (diaDexus Inc. manufacturer, South San Fransisco), a turbidimetric immunoassay, was used. oxLDL in EDTA plasma/serum/plasma heparin (oxLDL) was measured by sandwich /capture ELISA based on the mouse monoclonal antibody 4E6 (Mercodia, Uppsala, Sweden).

\section{STATISTICAL ANALYSIS}

Statistical analysis was done by SPSS for Windows $\mathrm{v} 17$ with a level at $\mathrm{p}<0.05$. The correlations between biomarkers were assessed by Pearson or Spearman's rho correlation test.

\section{Results}

Table 1 provides information on the general and biochemical characteristics of the study subjects. In general, the population characteristics of the subjects were in compliance with the inclusion and exclusion criteria. On each subject's characteristics we did normal distribution test (Kolmogorov Smirnov Test).

Table 1. General Characteristics of Subjects

\begin{tabular}{lcrrc}
\hline \multicolumn{1}{c}{ Variable } & Min & Max & Mean \pm SD & p \\
\hline Age (year) & 30.00 & 60.00 & $43.90 \pm 8.69$ & 0.165 \\
WC (cm) & 90.00 & 125.00 & $97.45 \pm 7.26$ & 0.016 \\
hsCRP $(\mathrm{mg} / \mathrm{L})$ & 0.29 & 8.53 & $1.84 \pm 1.59$ & 0.935 \\
Creatinine (mg/dL) & 0.60 & 1.20 & $0.90 \pm 0.12$ & 0.855 \\
eGFR (ng/mL) & 64.00 & 132.00 & $91.00 \pm 5.15$ & 0.029 \\
Lp-PLA2 (ng/mL) & 18.00 & 682.00 & $423.60 \pm 4.35$ & 0.082 \\
oxLDL (U/L) & 53.00 & 245.00 & $98.70 \pm 2.70$ & 0.271 \\
& & & & \\
\hline
\end{tabular}

WC $=$ Waist Circumference, hsCRP $=$ high sensitivity $\mathrm{C}-$ Reactive Protein; eGFR = estimate glomerolus filtration rate. 
Pearson or Spearman's correlations test was performed to assess correlation between parameters. The result showed positive correlation of oxLDL with central obesity based on waist circumference 90-110 $\mathrm{cm}(\mathrm{p}=0.040)$, hsCRP with oxLDL also showed linear correlation $(\mathrm{p}=0.047)$. This suggests that an increased waist circumference in inflammatory conditions contribute to the pathogenesis of atherosclerosis (Table 2).
The statistical analyses in this study showed a potential correlation of increased Lp-PLA2 > $422 \mathrm{ng} / \mathrm{mL}$ with atherosclerosis (oxLDL) in the group of centrally obese men. This finding indicated that high concentration of LpPLA2 contributes to the pathogenesis of atherosclerosis. This result is presented in a scatter graph, as shown in Figure 1.

Table 2. Correlation between WC, hs-CRP with oxLDL in Centrally Obese Men

\begin{tabular}{lcc}
\hline Variable & \multicolumn{2}{c}{ oxLDL } \\
& r & p \\
\hline WC & $0.258^{*}$ & 0.040 \\
hsCRP & $0.248^{\star}$ & 0.047 \\
\hline
\end{tabular}

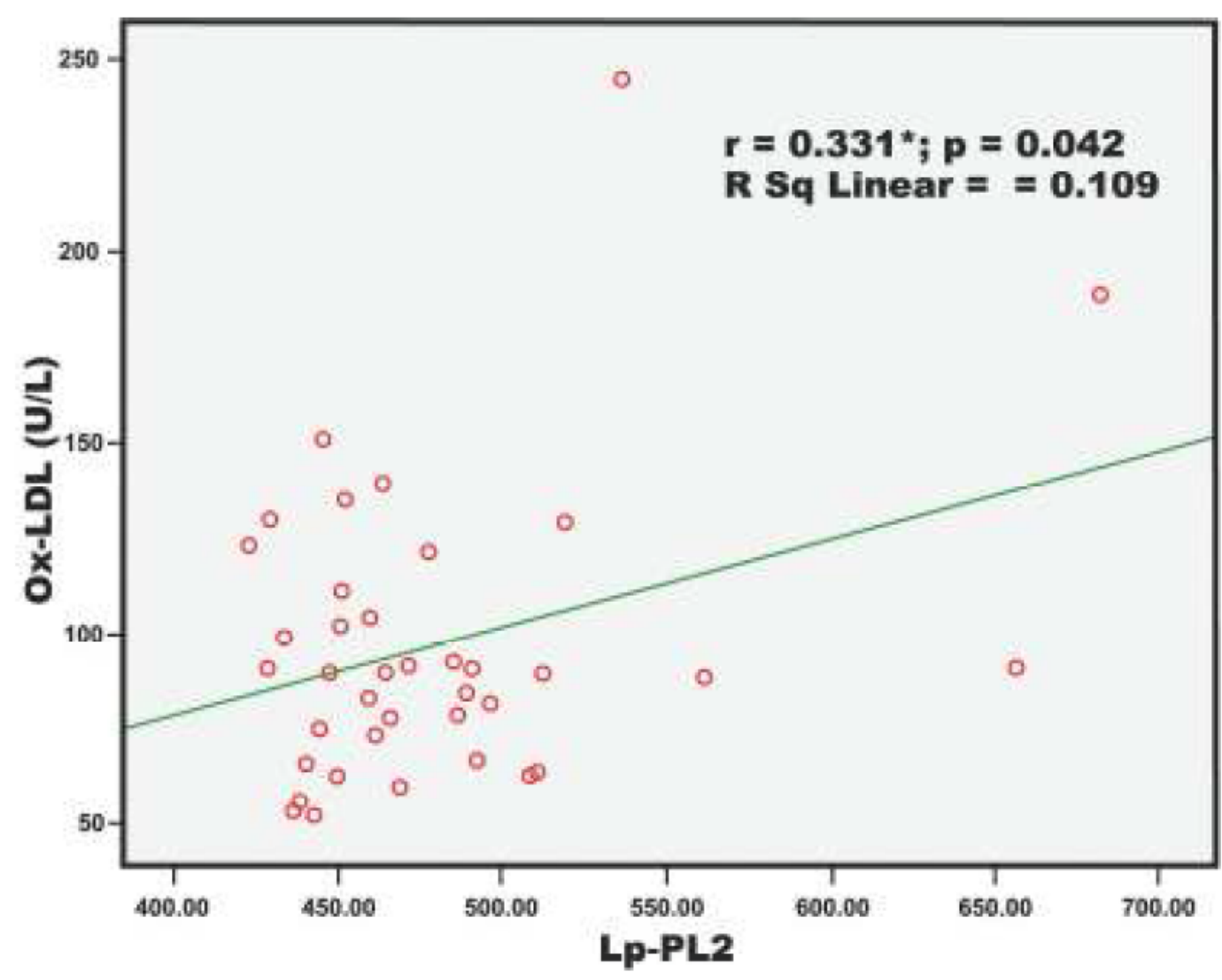

Figure 1. Correlation of Lp-PLA2 with oxLDL. 


\section{Discussions}

Results of this study showed relationship between central obesity and inflammatory condition with the pathogenesis of atherosclerosis as shown by the linear analysis results $(\mathrm{p}<0.05)$. In central obesity, adipocytes are stimulated to synthesize proinflammatory cytokines such as TNF- $\alpha$ and Interleukin-6. These cytokines constitute the main regulators of CRP synthesis. The level of hsCRP can be regarded as an atherosclerosis predictor. Obesity is associated with chronic low-grade inflammatory condition resulting from the adipose tissues. Inflammation triggered by obesity may accelerate the process of atherosclerosis (9).

In this study we found no correlation of hsCRP with Lp-PLA $A_{2}$. It is conceivable that these two biomarkers relate to different atherogenesis mechanisms. Jenny et al. examined the influence of CRP on Lp-PLA ${ }_{2}$ associations with cardiac events. In all of the models tested, there were no statistically significant multiplicative interactions of CRP with Lp-PLA 2 mass or activity. Addition of CRP (by cutpoints, $<1 \mathrm{mg} / \mathrm{L}, 1-3 \mathrm{mg} / \mathrm{L}, \geq 3 \mathrm{mg} / \mathrm{L}$ ) to the multivariable models for $\mathrm{Lp}-\mathrm{Lp}-\mathrm{PLA}_{2}$ mass or activity did not appreciably alter associations of these factors with CVD events. CRP and Lp-PLA ${ }_{2}$ were independent predictors of events and there was a significant additive effect when the biomarkers were combined (10).

In this study we found that Lp-PLA $>422 \mathrm{ng} / \mathrm{mL}$ had a linear correlation with oxLDL $(\mathrm{p}=0.042)$. This finding supports the previous studies that showed Lp-PLA $A_{2}$ was related to stroke occurrence (11). Other study found Lp$\mathrm{PLA}_{2}$ to be correlated with the increased incidence of heart attack and other death-causing vascular diseases (12). Lp$\mathrm{PLA}_{2}$ hydrolyzes oxidized phospholipid in oxLDL that results in lysophosphatylcholine and oxidixed fatty acid, which are proinflamatory substance and act to accelerate atherosclerosis process (13).

The most abundant oxPL in oxLDL is oxidized phosphatidylcolin (oxPC), which typically carries a truncated sn-2 acyl chain of nine carbons. oxPC is a specific substrate for the enzyme Lp-PLA, which release an oxidized short-chain fatty acid and lysophosphatidylcholine (LysoPC). LysoPC is a highly atherogenic lipid which induces multiple deleterious processes in the atherosclerotic plague (13).

Perssons et al. determined the relationship between Lp-PLA ${ }_{2}$, the metabolic syndrome and incident CVD in 4480 individuals. Lp-PLA 2 mass was significantly higher in the individuals with Mets. The combination of both MetS and increased Lp-PLA ${ }_{2}$ could, therefore be a prognostic marker for high-risk individuals (14).

Lp-PLA ${ }_{2}$ is secreted predominantly by the macrophage. Its expression and secretion significantly increase during differentiation of human monocytes into macrophages as well as dramatically increase during activation of macrophages in the atherosclerotic lesion. It is thought that in plasma, Lp-PLA $\mathrm{A}_{2}$ is circulating bound to $\mathrm{LDL}(80 \%)$ and HDL (20\%). Inhibiton of Lp-PLA activity will abolish the inflammatory response of the cells (15).

Vickers et al. observed that Lp-PLA $\mathrm{A}_{2}$ was significantly more abundant in atherosclerotic lesions than in normal tissue $(\mathrm{p}<0.05)$. This might explain why no correlation is found between low concentration of Lp-PLA 2 (> 422 $\mathrm{ng} / \mathrm{mL}$ ) and oxLDL in centrally obese men. Plasma Lp$\mathrm{PLA}_{2}$ levels represent risk related to the total burden of vascular inflammation and not just the burden arising from particular atheroma. Likewise, the plasma Lp-PLA 2 level reflects the contributing factors deriving from a single lesion, but mainly from multiple atherosclerotic sites (13).

\section{Conclusion}

This study showed a strong correlation between Lp-PLA $>422 \mathrm{ng} / \mathrm{mL}$ and oxLDL in centrally obese men $(\mathrm{r}=$ $0.331 * ; \mathrm{p}=0.042$ ).

\section{Acknowledgement:}

We would like to thank the Prodia Education and Research Institute, Research Support Department of Prodia Clinical Laboratory, Prodia Clinical Laboratory - Makassar, and Prodia Clinical Laboratory-Bandung, for their invaluable supports to this research.

\section{References:}

1. Trayhurn P. Adipocyte Biology. Obes Rev 2007; 8 (suppl. 1): 41-4.

2. Engfeldt $P$, Arner P. Lipolysis in human adipocytes, effects of cell size, age and of regional differences. Horm Metab Res Suppl. 1988; 19: 26-9.

3. Hosogai N, Fukuhara A, Oshima K, Miyata Y, Tanaka S, Segawa K, et al. Adipose tissue hypoxia in obesity and its impact on adipocytokine dysregulation. Diabetes 2007; 56: $901-11$

4. Thompson A, Gao P, Orfei L, Watson S, Di Angelantonio E, Kaptoge $S$ et al. Lipoprotein-associated phospholipase $\mathrm{A} 2$ and risk of coronary disease, stroke, and mortality: collaborative analysis of 32 prospective studies. Lancet 2010; 375: 1536-44. 
5. Ishigaki $Y$, Oka $Y$, Katagiri $H$. Circulating oxidized LDL: a biomarker and a pathogenic factor. Curr Opin Lipidol 2009; 20 : 363-9

6. Grundtman C, Wick G. The autoimmune concept of atherosclerosis. Curr Opin Lipidol 2011; 22: 327-34

7. Galle J, Hansen-Hagge T, Wanner C, Seibold S. Impact of oxidized low density lipoprotein on vascular cells. Atherosclerosis 2006; 185: 219-26

8. Tsimikas S. Oxidized low-density lipoprotein biomarkers in atherosclerosis. Curr Atheroscler Rep 2006; 8: 55-61

9. Lyon CJ, Law RE, Hsueh WA. Minireview ; Adiposity, Inflammation, and Atherogenesis. Endocrinology. 2003;144: 2195-200

10. Jenny NS, Solomon C, Cushman M, Tracy RP, Nelson JJ, Psaty BM, et al. Lipoprotein-associated phospholipase $\mathrm{A}(2)$ (Lp-PLA(2)) and risk of cardiovascular disease in older adults: results from the Cardiovascular Health Study. Atherosclerosis 2010; 209: 528-32

11. Saenger AK, Christenson RH. Stroke biomarkers: progress and challenges for diagnosis, prognosis, differentiation, and treatment. Clin Chem 2010; 56: 21-33

12. Corsetti JP, Rainwater DL, Moss AJ, Zareba W, Sparks CE. High Lipoprotein-Associated Phospholipase A2 Is a Risk Factor for Recurrent Coronary Events in Postinfarction Patients. Clin Chem 2006; 52: 1331-8.
13 Vickers KC, Maguire CT, Wolfert R, Burns AR, Reardon $M$, Geis R et al. Relationship of lipoprotein-associated phospholipase A2 and oxidized low density lipoproteinvin carotid atherosclerosis. J Lipid Res 2009; 50: 1735-42

14. Wrahle KWJ, Heys SD. Atherosclerosis : cell biology and lipoprotein. Curr Opin Lipidol 2008; 19: 435-7

15. Mohler ER, Ballantyne CM, Davidson $M H$, Hanefeld $M$, Ruilope LM, Johnson JL, et al. The effect of darapladib on plasma lipoprotein-associated phospholipase A2 activity and cardiovascular biomarkers in patients with stable coronary heart disease or coronary heart disease risk equivalent: the results of a multicenter, randomized, double-blind, placebo-controlled study". J. Am. Coll. Cardiol. 2008; 51: 1632-41

16. O'Donoghue M, Morrow DA, Sabatine MS, Murphy SA, McCabe $\mathrm{CH}$, Cannon $\mathrm{CP}$, et al. Lipoprotein-associated phospholipase A2 and its association with cardiovascular outcomes in patients with acute coronary syndromes in the PROVE IT-TIMI 22 (PRavastatin Or atorVastatin Evaluation and Infection Therapy-Thrombolysis In Myocardial Infarction) Trial. Circulation 2006; 113: 174552.

17. Ballantyne $\mathrm{CM}$, Hoogeveen $\mathrm{RC}$, Bang $\mathrm{H}$, et al. Lipoproteinassociated Phospholipase A2, High-Sensitivity C-Reactive Protein, and Risk for Incident Ischemic Stroke in Middle-aged Men and Women in the Atherosclerosis Risk in Communities (ARIC) Study. Arch Intern Med 2005; 165: 2479-84. 